\title{
Morphometric Analysis of the Banas River Basin Using the Geographical Information System, Rajasthan, India
}

\author{
Swatantra Kumar Dubey, Devesh Sharma*, Nitika Mundetia \\ Department of Environmental Sciences, Central University of Rajasthan, Bandarsindri, Ajmer, Rajasthan, India \\ Email address: \\ swatantratech1@gmail.com (S. K. Dubey),devesh.water@gmail.com (D. Sharma), nitikacuraj@gmail.com (N. Mundetia) \\ To cite this article: \\ Swatantra Kumar Dubey, Devesh Sharma, Nitika Mundetia. Morphometric Analysis of the Banas River Basin Using the Geographical \\ Information System, Rajasthan, India. Hydrology. Vol. 3, No. 5, 2015, pp. 47-54. doi: 10.11648/j.hyd.20150305.11
}

\begin{abstract}
Geographical Information System techniques have been used for the identification of geomorphological features and analyzing the properties of the Banas River basin area in Rajasthan state, India. The Banas basin has covered an area of $51,779 \mathrm{~km}^{2}$. For this study, the Shuttle Radar Topographic Mission (SRTM) Digital Elevation Model (DEM) is used for evaluation of morphometric components like linear, areal and relief aspects with the help of ArcGIS software. Morphometric analysis of river basin was performed by determining the parameters like drainage area; gradient, relief; linear and aerial aspects. Watershed boundary, flow direction, flow accumulation, flow length, stream ordering have been prepared using hydrological tool and slope-aspect have been prepared using surface tool in ArcGIS. These results may be used in basin management development and hydrological studies.
\end{abstract}

Keywords: Morphometric Analysis, Geomorphology, DEM, Banas River Basin

\section{Introduction}

Morphometric analysis is a mathematical Representation of earth's surface [1]. Morphometric analysis of a basin provides information about different aspects and characterizes the drainage system of basin in these aspects [2]. National Institute of Hydrology (1993) has studied the morphometric analysis of various basins and it was based on linear, aerial and relief aspects using different mathematical equations. The morphometric analysis can be done through measurement of different aspects like linear, aerial, relief, channel network, aspect and slope of the basin [3, 4]. A Morphometric characteristic of hydrologic and geomorphic processes gives the information about the watershed formation in different scale [5]. The runoff of different catchment area and the geomorphologic structure are very sensitive and its dynamic nature was controlled by runoff and this structure gives the morphometric characteristics of the catchment of contributing area [6]. There are many morphological parameters such as stream length, stream number, stream order, drainage pattern; drainage density, bifurcation ratio and other linear aspects and relief aspects are studied using remote sensing and GIS technique and also a topographical map [7]. Digital Elevation Model (DEM) data were used for landscaping and also used for generating the elevation model to use the digital elevation data. The DEM file was used for generating the hydrological component of the basin like flow direction, flow accumulation, stream network and other layers that were supporting the morphometric analysis [7]. Some author used morphometric analysis in coastal area, river structure and some are using bearing azimuth and drainage (bAd) calculator $[8,9,10]$. This study evaluates the various morphometric parameters of the Banas River Basin in Rajasthan using Geographical Information Systems (GIS) techniques.

\section{Study Area Description}

River Banas is located in east-central Rajasthan state (India). It originates in the Khamnor hills of the Aravali range and flows in Rajasthan. Banas is a major tributary of the River Chambal, which is again a tributary of River Ganga. The total catchment area is about $51,779 \mathrm{~km}^{2}$ with a length of about $512 \mathrm{~km}$. Banas River Basin also sub-divided into $9 \mathrm{sub}$ basins. The catchment area of all these sub basins along with district coverage is shown in Fig.1.TheBanas River passes through the 13districts namely, Sawai Madhopur, Jaipur, Ajmer, Tonk, Rajsamand, Banswara, Chittaurgarh, Udaipur, Bhilwara, Dausa, Sikar, Nagaur and Karauli. 


\section{Data Used and Methodology}

The extraction of drainage network has been done from the SRTM-DEM with $90 \mathrm{~m}$ spatial resolution. The generation of depression less DEM is always the preparatory step for morphometric analysis of drainage basin. Hydrology tool under Spatial Analyst Tools in ArcGIS-10 software was used to extract drainage channels, and other parameters that were shown in Table 1. The automated method for delineating streams followed a series of steps, i.e. DEM, fill, flow direction, flow accumulation, watershed, and stream order. Thereafter, morphometric parameters have been computed for the entire Banas River basin. The morphometric parameters have been evaluated from four different aspects, i.e. drainage network, basin geometry, drainage texture, and relief (Table 1). The different parameters were then correlated to understand how they interact with and influence each other.

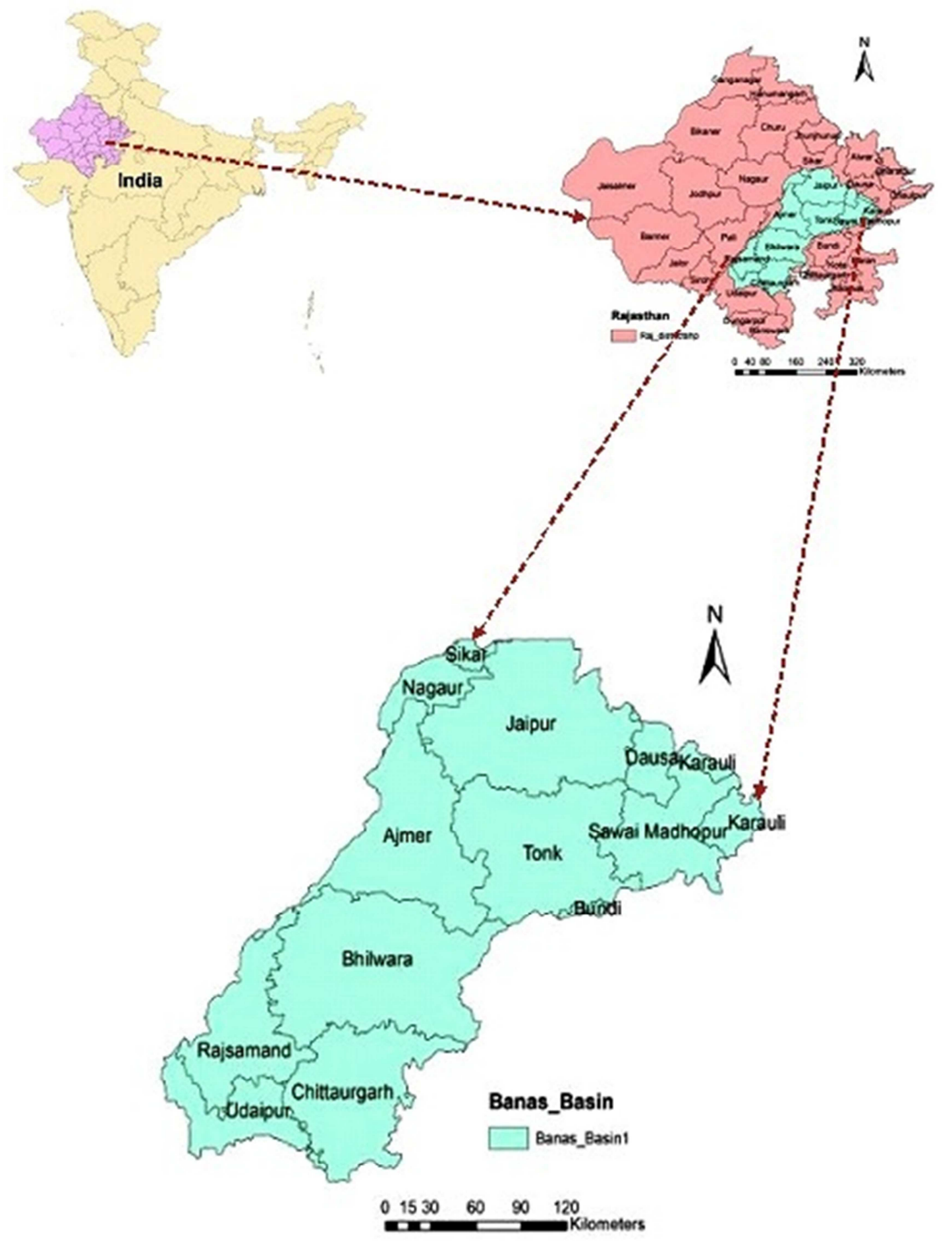

Figure 1: Map of Banas River basin of Rajasthan. 
Table 1: Methodology adopted for computation of morphometric parameters.

\begin{tabular}{|c|c|c|}
\hline \multicolumn{3}{|l|}{ Drainage Network } \\
\hline & Formula & Reference \\
\hline Stream order & Hierarchical Rank & Strahler (1952) [11] \\
\hline Total Stream order & Sum of Stream order & \\
\hline Stream number $(\mathrm{Nu})$ & $\mathrm{Nu}=\mathrm{N} 1+\mathrm{N} 2+\ldots \ldots . .+\mathrm{Nn}$ & Horton (1945) [14] \\
\hline Stream length $(\mathrm{Lu})(\mathrm{km})$ & Length of the stream & Strahler (1964) [2] \\
\hline Total Stream length $(\mathrm{km})$ & $\mathrm{Lu}=\mathrm{L} 1+\mathrm{L} 2 \ldots \ldots+\mathrm{Ln}$ & Strahler (1964) [2] \\
\hline Mean stream length $(\mathrm{km})(\mathrm{Lsm})$ & $\mathrm{Lsm}=\mathrm{Lu} / \mathrm{Nu}$ & Strahler (1964) [2] \\
\hline Stream length ratio (Lur) & $\mathrm{Lur}=\mathrm{Lu} /(\mathrm{Lu}-1)$ & Strahler (1964) [2] \\
\hline Bifurcation ratio $(\mathrm{Rb})$ & $\mathrm{Rb}=\mathrm{Nu} / \mathrm{Nu}+1$ & Strahler (1964) [2] \\
\hline Rho Coefficient ( $\rho$ ) & $\rho=$ Lur $/ R b$ & Horton (1945) [14] \\
\hline Mean bifurcation ratio (Rbm) & & Strahler (1964) [2] \\
\hline Perimeter $(\mathrm{P})(\mathrm{km})$ & GIS Software & Schumm (1956) [13] \\
\hline Basin length (Lb) (km) & GIS Software & Schumm (1956) [13] \\
\hline Basin area $\left(\mathrm{km}^{2}\right)(\mathrm{A})$ & GIS Software & Schumm (1956) [13] \\
\hline Mean Basin Width (Wb) & $\mathrm{Wb}=\mathrm{A} / \mathrm{Lb}$ & Horton (1932) [12] \\
\hline Relative Perimeter $(\operatorname{Pr})$ & $\operatorname{Pr}=A / P$ & Schumm (1956) [13] \\
\hline Length Area Relation (Lar) & $\operatorname{Lar}=1.4 * \mathrm{~A}^{0.6}$ & Hack (1957) [15] \\
\hline Lemniscate's (k) & $\mathrm{k}=\mathrm{Lb}^{2} / \mathrm{A}$ & Chorley (1957) [16] \\
\hline Form Factor Ratio (Rf) & $\mathrm{Ff}=\mathrm{A} / \mathrm{Lb}^{2}$ & Horton (1932) [12] \\
\hline Shape Factor Ratio (Rs) & $\mathrm{Sf}=\mathrm{Lb}^{2} / \mathrm{A}$ & Horton (1932) [12] \\
\hline \multicolumn{3}{|l|}{ Drainage Texture Analysis } \\
\hline Drainage Density (D) & $\mathrm{Dd}=\mathrm{Lu} / \mathrm{A}$ & Horton (1932) [12] \\
\hline Stream Frequency $(\mathrm{Fs})$ & $\mathrm{Fs}=\mathrm{Nu} / \mathrm{A}$ & Horton (1932) [12] \\
\hline Drainage Texture (Rt) & $\mathrm{Dt}=\mathrm{Nu} / \mathrm{P}$ & Horton (1945) [14] \\
\hline Circularity Ratio (Rc) & $\mathrm{Rc}=12.57 *\left(\mathrm{~A} / \mathrm{P}^{2}\right)$ & Miller (1953) [17] \\
\hline Length of Overland Flow (Lg) & $\mathrm{Lg}=\mathrm{A} / 2 * \mathrm{Lu}$ & Horton (1945) [14] \\
\hline Drainage Intensity (Di) & $\mathrm{Di}=\mathrm{Fs} / \mathrm{Dd}$ & Faniran (1968) [18] \\
\hline Constant of Channel Maintenance & $\mathrm{C}=1 / \mathrm{Dd}$ & Schumm (1956) [13] \\
\hline Infiltration Number & If $=\mathrm{Fs} * \mathrm{Dd}$ & Faniran (1968) [18] \\
\hline \multicolumn{3}{|l|}{ Relief Characterization } \\
\hline Height of basin mouth (z) & GIS Analysis / DEM & \\
\hline Maximum height of the basin $(\mathrm{Z})$ & GIS Analysis / DEM & \\
\hline Total Basin relief $(\mathrm{H})(\mathrm{m})$ & $\mathrm{H}=\mathrm{Z}-\mathrm{z}$ & Strahler (1952) [11] \\
\hline Relief ratio $(\mathrm{Rhl}) \mathrm{m}$ & $\mathrm{Rhl}=\mathrm{H} / \mathrm{Lb}$ & Schumm (1956) [13] \\
\hline Relative Relief Ratio (Rhp) & $\mathrm{Rhp}=\mathrm{H} * 100 / \mathrm{P}$ & Melton (1957) [19] \\
\hline Gradient Ratio (Rg) & $\operatorname{Rg}=(Z-z) / L b$ & Sreedevi (2004) [20] \\
\hline Ruggedness Number (Rn) & $\mathrm{Rn}=\mathrm{Dd} *(\mathrm{H} / 1000)$ & Patton \& Baker (1976) [21] \\
\hline Maelton Ruggedness Number (MRn) & $\mathrm{MRn}=\mathrm{H} / \mathrm{A}^{0.5}$ & Melton (1965) [23] \\
\hline Watershed Slope (Sw) & $\mathrm{Sw}=\mathrm{H} / \mathrm{Lb}$ & \\
\hline Slope Analysis (Sa) (deg) & GIS Analysis / DEM & \\
\hline Average Slope (S) \% & $\mathrm{S}=(\mathrm{Z} *(\mathrm{Ctl} / \mathrm{H})) /(10 * \mathrm{~A})$ & Wenthworth's (1930) [22] \\
\hline
\end{tabular}

Table 2: Stream Information for the Banas River basin.

\begin{tabular}{|c|c|c|c|c|c|c|c|c|c|}
\hline \multicolumn{2}{|c|}{$\begin{array}{l}\text { Stream } \\
\text { order }\end{array}$} & \multirow{2}{*}{$\begin{array}{l}\text { Total Stream } \\
\text { order }\end{array}$} & \multirow{2}{*}{$\begin{array}{l}\begin{array}{l}\text { Stream } \\
\text { number }(\mathbf{N u})\end{array} \\
121\end{array}$} & \multirow[t]{2}{*}{$\begin{array}{l}\text { Total Stream } \\
\text { Number } \\
\end{array}$} & \multicolumn{2}{|c|}{$\begin{array}{l}\text { Number of stream } \\
\text { used in the ratio }\end{array}$} & \multirow{2}{*}{$\begin{array}{l}\begin{array}{l}\text { Stream length } \\
(\mathbf{L u})(\mathbf{k m})\end{array} \\
1401.9\end{array}$} & \multirow[t]{2}{*}{$\begin{array}{l}\text { Total Stream } \\
\text { length }(\mathbf{k m})\end{array}$} & \multirow{2}{*}{$\begin{array}{l}\text { Mean stream length } \\
\text { (km) (Lsm) }\end{array}$} \\
\hline $\mathrm{I}$ & 2819 & & & & $\mathrm{I}+\mathrm{II}$ & 177 & & & \\
\hline II & 1839 & \multirow{3}{*}{5856} & 56 & \multirow{3}{*}{209} & $\mathrm{II}+\mathrm{III}$ & 79 & 931 & \multirow{3}{*}{2939.5} & 0.506 \\
\hline III & 753 & & 23 & & $\mathrm{III}+\mathrm{IV}$ & 32 & 381.6 & & 0.507 \\
\hline IV & 445 & & 9 & & & & 225 & & 0.506 \\
\hline
\end{tabular}

\section{Results and Discussion}

The morphometric analysis of the Banas River Basin was carried out on the SRTM-DEM with $90 \mathrm{~m}$ spatial resolution. The streams length measure by using the ArcGIS-10 software and Arc-Hydrology tool has been used for stream ordering. The methods of Strahler (1953), Chorley (1957), Horton (1945) were used for linear aspects studies, for areal aspects study using Strahler (1952), Miller (1953), Horton (1932) and Schumm (1956) technique, and the technique applies to relief aspects are Horton (1945), Strahler (1952) and Melton
(1957). Wentworth (1930) method was used for the average slope analysis of the watershed. ArcGIS- 10 were used for analysis of the Perimeter(P), Basin Length (lb), Basin Area (A), Height of basin mouth (z), Maximum height of the basin (Z), Total Contour Length (Ctl) and Contour Interval (Cin).

\subsection{Stream order (Nu)}

For drainage basin analysis, flow accumulation and stream order were determined using the DEM as shown in Fig. 2. According to Strahler (1964), are designated as Stream order 1 to 4 . The 5856 numbers of streams were identified and from which 2819 are first order streams, 1839 are second order, 
753 are third order, 445 in fourth order (Fig. 3).

\subsection{Stream Length (Lu)}

Stream length is a significant hydrological feature of the basin and it shows surface runoff characteristics. As shown in table 2, Total stream length of the basin was $2939.5 \mathrm{~km}$, first order is $1401.9 \mathrm{~km}, 931 \mathrm{~km}$ for second order, $381.6 \mathrm{~km}$ for third order and $225 \mathrm{~km}$ for fourth order.

\subsection{Bifurcation Ratio (Rb)}

Bifurcation Ratio is calculated by dividing the number of streams in the lower by the number in the higher of the two orders. For river basin the $\mathrm{Rb}$ is showing the range between 2.0 to 3.0 but generally natural drainage systems have $\mathrm{Rb}$ values between 3.0 and 5.0 [2]. In the study mean bifurcation ratio $(\mathrm{Rbm})$ is 2.384 which suggest less structural disturbance.

\subsection{Length of the Basin (Lb)}

The basin length is the longest part of the basin parallel to the principal drainage line defined by Schumm (1956). The equation Schumm (1956) used for calculation of stream length that is $2939.5 \mathrm{~km}$ (Table 2).

\subsection{Form Factor Ratio (Rf)}

Form factor ( $\mathrm{Rf}$ ) is defined the basin area (A) divide the square of basin length (Lb) it is defined by Horton 1932. The form factor value for Banas River basin is 0.411 indicating an elongated basin in shape.

\subsection{Circularity Ratio (Rc)}

The range of Circularity ratios is 0.4 to 0.5 which is described by Miller (1953). The circularity ratio value 0.284 indicating that the catchment is characterized by elongated shape, low discharge of runoff and high permeability of the subsoil conditions. The circularity ratio is influenced by stream length, stream frequency (Fs), geological structures, land cover, climate, relief and slope of the basin. It is an important parameter, which indicates the stage of the basin.

\subsection{Rho Coefficient ( $\rho)$}

The Rho coefficient is an important parameter described by the (Horton 1945) using the stream length ratio divided by the Bifurcation ratio $(\mathrm{Rb})$. The Rho values of the Banas River basin are 0.701 (Table 3 ).

Table 3: Morphometric parameters calculated for the Banas River basin.

\begin{tabular}{|c|c|c|c|c|c|c|c|}
\hline \multicolumn{2}{|c|}{ Stream length ratio (Lur) } & \multicolumn{2}{|c|}{ Bifurcation ratio (Rb) } & \multirow{2}{*}{$\begin{array}{l}\text { Rho Coefficient ( } \boldsymbol{\rho}) \\
0.301\end{array}$} & \multirow[t]{2}{*}{$\begin{array}{l}\text { Mean bifurcation ratio } \\
(\mathrm{Rbm})\end{array}$} & \multirow[t]{2}{*}{$\begin{array}{l}\text { Form Factor } \\
\text { Ratio (Rf) } \\
\end{array}$} & \multirow[t]{2}{*}{$\begin{array}{l}\text { Shape Factor } \\
\text { Ratio (Rs) }\end{array}$} \\
\hline $\mathrm{II} / \mathrm{I}$ & 0.652 & $\mathrm{I} / \mathrm{II}$ & 2.16 & & & & \\
\hline III/II & 0.409 & II/III & 2.43 & 0.168 & \multirow[t]{2}{*}{2.384} & \multirow[t]{2}{*}{0.411} & \multirow[t]{2}{*}{2.434} \\
\hline IV/III & 0.591 & III/IV & 2.56 & 0.231 & & & \\
\hline
\end{tabular}
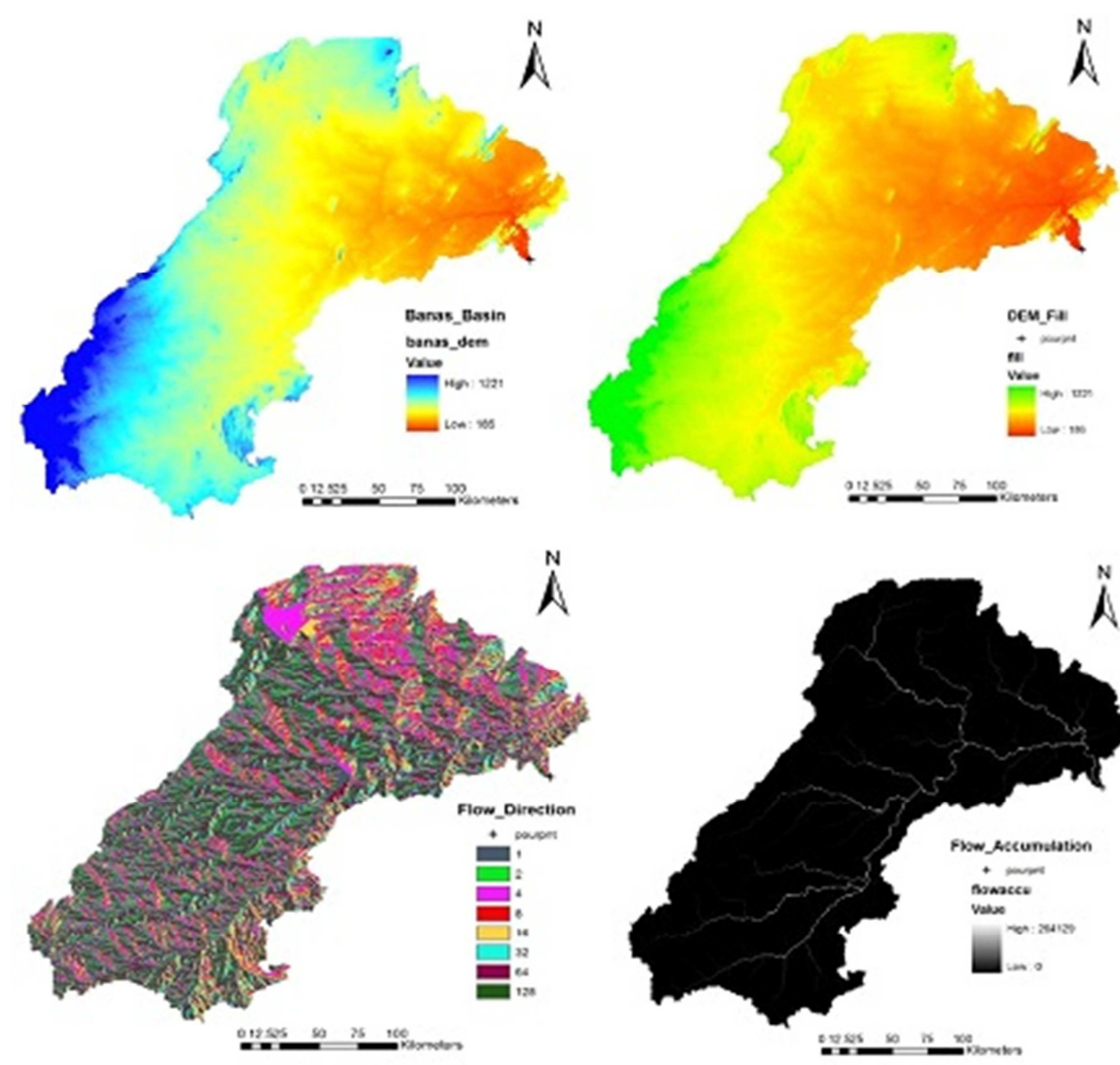

Figure 2: Process of flow accumulation using the ArcGIS Hydrological tool. 
Table 4: Basin Geometry calculated for Banas River basin.

\begin{tabular}{lllllc}
\hline $\begin{array}{l}\text { Perimeter } \\
(\mathbf{P})(\mathbf{k m})\end{array}$ & $\begin{array}{l}\text { Basin length } \\
(\mathbf{L b})(\mathbf{k m})\end{array}$ & $\begin{array}{l}\text { Basin area }\left(\mathbf{k m}^{2}\right) \\
(\mathbf{A})\end{array}$ & $\begin{array}{l}\text { Mean Basin } \\
\text { Width }(\mathbf{W b})\end{array}$ & $\begin{array}{l}\text { Relative } \\
\text { Perimeter (Pr) }\end{array}$ & Length Area Relation $(\mathbf{L a r})$ \\
\hline 1514 & 355 & 51779 & 145.856 & 34.200 & 943.235 \\
\hline
\end{tabular}

\subsection{Basin Area (A)}

The area is an important parameter like Perimeter, stream order, drainage density and stream length. Schumm (1956) established a relation between the total watershed areas and the total stream lengths. Using GIS software for basin area calculation, which is $51779 \mathrm{sq} \mathrm{km}$ (Table 4).

\subsection{Basin Perimeter (P)}

Perimeter of Banas basin is calculated by using ArcGIS-10 software; the basin perimeter come1514 Km is covering Rajasthan districts (Table 4).

\subsection{Length Area Relation (Lar)}

For Length Area Relation using Lar $=1.4 * \mathrm{~A}^{0.6}$ formula given by Hack (1957) to calculate the length area relation for a large number of basins. The value of Length Area Relation is 943.235 (Table 4).

\subsection{Lemniscate's ( $k$ )}

For slope determination of the basin lemniscate's value is calculated by Chorely (1957).The value of the $\mathrm{k}$ for the Banas River basin is 2.434 (Table 4).

\subsection{Constant of Channel Maintenance (1/D)}

Schumm (1956) has used the inverse of the drainage density having the dimension of length as a property termed constant of channel maintenance. Channel maintenance, constant of the Banas basin is $17.615 \mathrm{~km}$ (Table 5).

\subsection{Drainage Density (D)}

Horton (1932) explains the drainage density; the ratio of total stream lengths divided the basin area, drainage density expressed in terms of $\mathrm{km} / \mathrm{km}^{2}$. The drainage density value of Banas Basin watersheds is 0.057.The drainage density indicates the closeness of spacing of channels, thus determines the time of travel by water.

\subsection{Drainage Intensity (Di)}

Drainage intensity explains by Faniran 1968, the stream frequency was divided by the drainage density. The result indicates low drainage intensity, i.e. 0.071 shown in (Table 5).

\subsection{Length of Overland Flow (Lg)}

Over land area is defined as half of the reciprocal of drainage density. It is one of the most important independent variables, affecting both the hydrological and physiographical developments of the drainage basin (Horton 1945). The calculated length of overland flow of the study area is $8.807 \mathrm{~km}$.

\subsection{Stream Frequency (Fs)}

Stream frequency (Fs) is the total number of stream segments of all orders per unit area (Horton, 1932). Values of Stream frequency of Banas Basin are 0.004. When the stream, frequency (Fs) has low values it indicate the presence of a low relief and permeable subsurface material (Reddy et al. 2004a)

\subsection{Drainage Texture (Rt)}

Drainage texture is defined by Horton (1945) as the total number of streams divided by the perimeter. In terms of the drainage texture Banas Basin falls in the category of moderate drainage texture. The Drainage texture of basins depends on climate, rainfall, vegetation, soil and rock types, infiltration rate, relief and the stages of development.

\subsection{Infiltration Number (If)}

Drainage density and stream frequency of a watershed show the infiltration number it is defined by Faniran 1968. The value of infiltration number is 0.061 (Table 5).

\subsection{Relief Ratio (Rhl)}

The relief ratio is defined as the ratio between the total relief of a basin and basin length (Schumm, 1956). It is influenced by the slope of the basin and rock characteristics. High and low value shows the hilly and plain region in the basin. In the study area, the value of relief ratio is $2.9183 \mathrm{~m}$ (Table 6).

\subsection{Relative Relief (Rhp)}

Relative relief is calculated by using perimeter and total basin relief to introduce by Melton's (1957). It comes to 68.4280 for the Banas River basin.

\subsection{Ruggedness Number (Rn)}

Ruggedness number is computed by the total basin relief and the drainage density Strahler's (1968). Ruggedness number of the Banas River basin has 0.0588 (Table 6). Rn indicates the structural complexity of the terrain in association with relief and drainage density.

\subsection{Melton Ruggedness Number (MRn)}

The MRn is calculated by using total basin relief divided by total basin areas of the watershed (Melton 1965). The Melton Ruggedness Number of Banas Basin is 0.04 (Table 6).

\subsection{Slope Analysis (Sa)}

Slope map has created by using Surface Analysis Tool in 
ArcGIS-10, which is $0^{\circ}$ to $12^{\circ} 45^{\prime}$ (Table 7). The slope can be expressed in degrees or percentage.

\subsection{Average Slope (S)}

According to Wenthworth's (1930), the average slope of the watershed is determined by using the basin area (A), total basin relief $(\mathrm{H})$, maximum height of the basin $(\mathrm{Z})$ and total contour length. The average slope of the Banas Basin was calculated $0.0008 \%$ (Table 7).

\subsection{Aspect}

The aspect refers to the direction of terrain faces. Aspect influences by some components, i.e. vegetation, settlement, agriculture, precipitation, melting of snow and wind. The direction of the aspect was derived in $0^{\circ}$ is true north; a $90^{\circ}$ aspect is to the east. The aspect map of the Banas Basin River is shown in Fig. 4.

Table 5: Drainage Texture calculated for Banas River basin.

\begin{tabular}{llllllll}
\hline $\begin{array}{l}\text { Drainage } \\
\text { Density (D) }\end{array}$ & $\begin{array}{l}\text { Stream } \\
\text { Frequency (Fs) }\end{array}$ & $\begin{array}{l}\text { Drainage } \\
\text { Texture (Rt) }\end{array}$ & $\begin{array}{l}\text { Circularity } \\
\text { Ratio (Rc) }\end{array}$ & $\begin{array}{l}\text { Length of Overland } \\
\text { Flow (Lg) }\end{array}$ & $\begin{array}{l}\text { Drainage } \\
\text { Intensity (Di) }\end{array}$ & $\begin{array}{l}\text { Constant of Channel } \\
\text { Maintenance }\end{array}$ & $\begin{array}{l}\text { Infiltration } \\
\text { Number (If) }\end{array}$ \\
\hline 0.057 & 0.004 & 0.138 & 0.284 & 8.807 & 0.071 & 17.615 & 0.061 \\
\hline
\end{tabular}

Table 6: Relief Characterization for Banas River basin.

\begin{tabular}{llllllll}
\hline $\begin{array}{l}\text { Height of basin } \\
\text { mouth }(\mathbf{z})\end{array}$ & $\begin{array}{l}\text { Maximum height } \\
\text { of the basin }(\mathbf{Z})\end{array}$ & $\begin{array}{l}\text { Total Basin } \\
\text { relief }(\mathbf{H})(\mathbf{m})\end{array}$ & $\begin{array}{l}\text { Relief ratio } \\
(\mathbf{R h I}) \mathbf{m}\end{array}$ & $\begin{array}{l}\text { Relative Relief } \\
\text { Ratio (Rhp) }\end{array}$ & $\begin{array}{l}\text { Gradient } \\
\text { Ratio (Rg) }\end{array}$ & $\begin{array}{l}\text { Ruggedness } \\
\text { Number }(\mathbf{R n})\end{array}$ & $\begin{array}{l}\text { Maelton Ruggedness } \\
\text { Number (MRn) }\end{array}$ \\
\hline 1221 & 185 & 1036 & 2.9183 & 68.428 & 2.9183 & 0.0588 & 0.04 \\
\hline
\end{tabular}

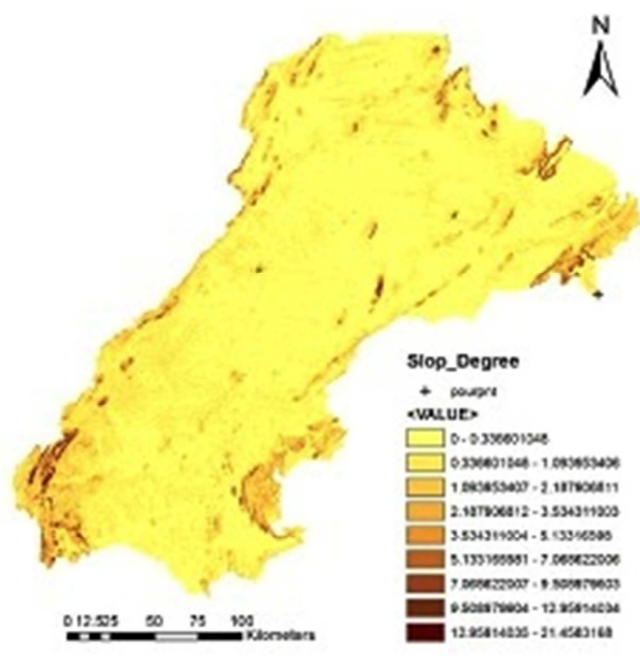

A

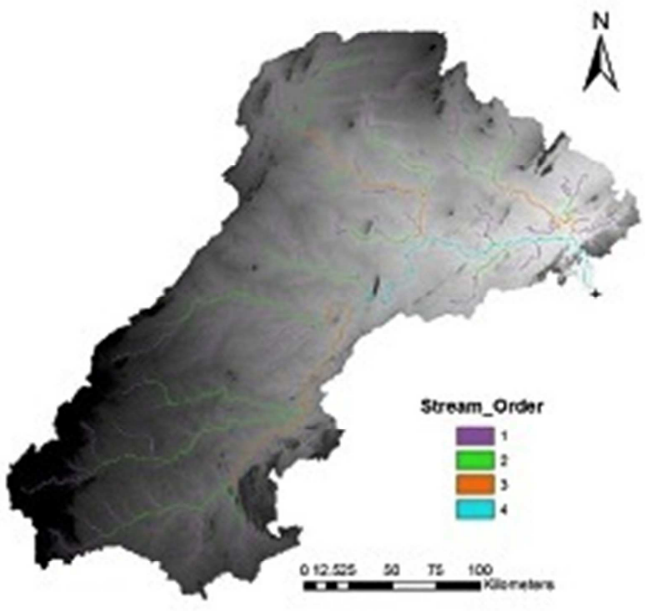

$\mathrm{C}$

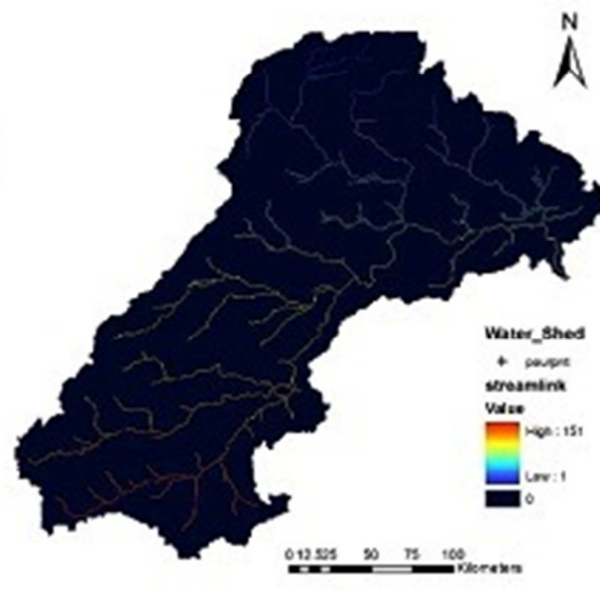

B

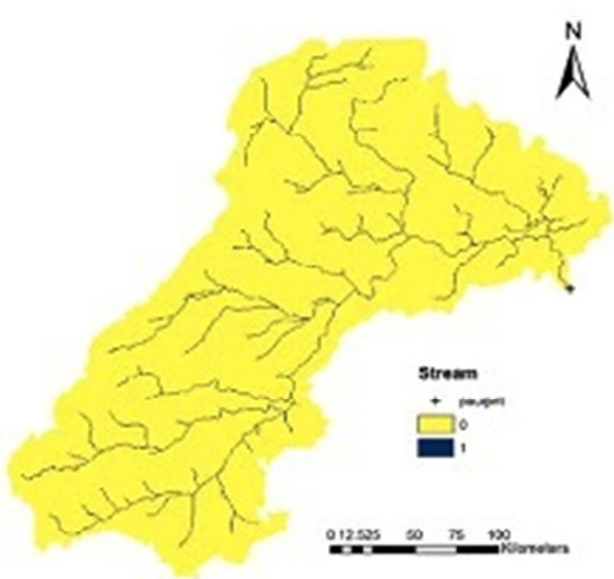

D

Figure 3: Map shows (A) Slope (B) Watershed (C) Stream order (D) Stream link. 
Table 7: Slope Characterization for Banas River basin.

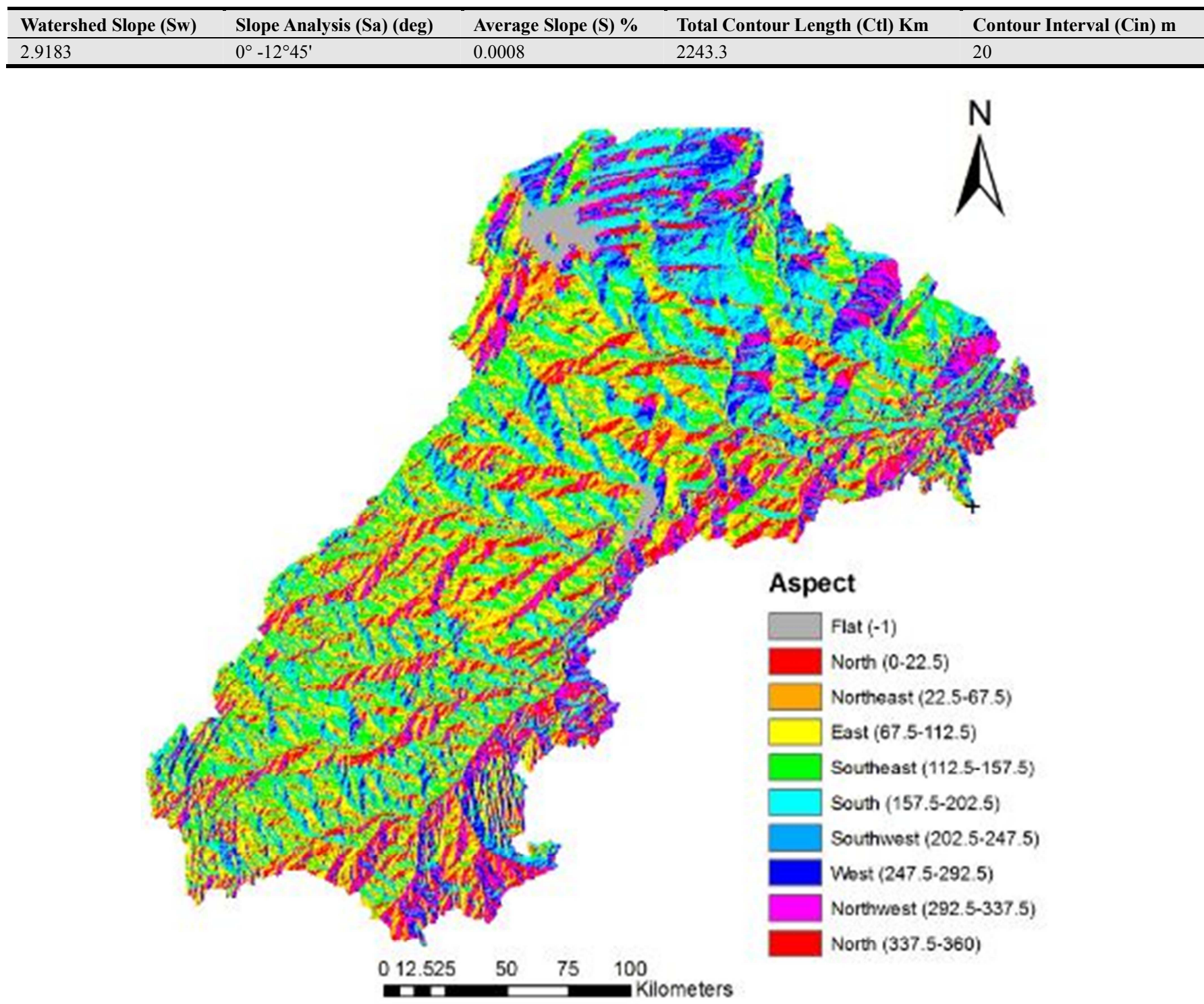

Figure 4: Aspect map of Banas River basin.

\section{Conclusion}

Morphometric parameters of the basin has been computed and analyzed by using geoprocessing technique of ArcGIS and explore the relationship between the drainage morphometry, moderate and high relief, low run off and high infiltrations. Morphometric parameters were analyzed by measurement of linear, areal and relief aspects. The bifurcation ratio and drainage density shows the normal watershed, moderate permeable soil and coarse drainage texture. In this study, it is observed the average values of drainage density and stream frequency are nearly similar with positive correlation. High resolution satellite data in different geological and climatic conditions help in better understanding the status of landforms and other parameters like urban planning, transportation planning, ecologicaleconomic zoning, environmental issues, hazard mitigation, urban drainage, erosion dynamics of land and soil.

\section{References}

[1] Clarke J I, (1996) Morphometry from maps: essay in geomorphology, Elsevier Publ, Co, New York, pp 235-274.

[2] Strahler A N, (1964) Quantitative geomorphology of drainage basins and channel networks In: Chow Ven Te (Ed) Handbook of applied hydro McGraw Hill Book Company, New York.

[3] Nag S K and Chakraborty S (2003) Influence of rock types and structures in the development of drainage network in hard rock area, J Indian Soc Remote Sens 31 (1):25-35.

[4] Magesh N S, Jitheshlal K V, Chandrasekar N and Jini K V (2012b) GIS based morphometric evaluation of Chimmini and Mupily watersheds, parts of Western Ghats, Thrissur District, Kerala, India, Earth Sci Inform 5 (2) :111-121. 
[5] Singh S and Singh M C (1997) Morphometric analysis of Kanhar river basin, Nat Geogra J of India 43, 1: 31-43.

[6] Rudraiah M, Govindaiah S and Srinivas V S (2008) Morphometry using remote sensing and GIS techniques in the sub-basins of Kagna river basin, Gulburga district, Karnataka, India, J Indian Soc Remote Sens 36:351-360.

[7] Mesa L M (2006) Morphometric analysis of a subtropical Andean basin (Tucuman, Argentina), Environ Geol 50 (8): $1235-1242$.

[8] Basso A, Bruno E, Parise M and Pepe M (2013) Morphometric analysis of sinkholes in a karst coastal area of southern Apulia (Italy), Environmental Earth Sciences 70(6), 2545-2559.

[9] Angillieri M Y E and Perucca L P (2014) Geomorphology and morphometry of the de La Flecha river basin, San Juan, Argentina, Environmental Earth Sciences, 1-11.

[10] Markose V J, Dinesh A C and Jayappa K S (2014) Quantitative analysis of morphometric parameters of Kali River basin, southern India, using bearing azimuth and drainage (bAd) calculator and GIS, Environmental Earth Sciences, 1-17.

[11] Strahler A N (1952) Hypsometric Analysis of Erosional Topography, Bulletin of the Geological Society of America 63, pp 1117-42.

[12] Horton R E (1932) Drainage Basin Characteristics Transactions, American Geophysical Union, 13, pp 350-61.

[13] Schumm S A (1956) Evolution of Drainage Systems \& Slopes in Badlands at Perth Anboy, New Jersey, Bulletin of the Geological Society of America 67, pp 597-646.

[14] Horton R E (1945) Erosional Development of Streams and their Drainage Basins, Bulletin of the Geological Society of America 56, pp-275-370.

[15] Hack J T (1957) Studies of longitudinal stream profiles in Virginia and Maryland.

[16] Chorley, RL, (1967) Models in Geomorphology in RJ Chorley and P Haggett (eds), Models in Geography, London pp 59-96.

[17] Miller V C (1953) A quantitative geomorphic study of drainage basin characteristics on the Clinch Mountain area, Virgina and Tennessee, Columbia University, Department of Geology, Technical Report, Number 3, pp 389-402, ONR, New York.

[18] Faniran A (1968) The Index of Drainage Intensity - A Provisional New Drainage Factor, Australian J of Sci 31, pp 328-330.

[19] Melton M A (1957) An Analysis of the relations among Elements of Climate, Surface Properties and Geomorphology, Project NR 389042, Tech Rep 11, Columbia University.

[20] Sreedevi P D, Subrahmanyam K and Shakeel A (2005) The significance of morphometric analysis for obtaining groundwater potential zones in a structurally controlled terrain, J Environ Geol Vol 47, No 3, pp 412-420.

[21] Patton P C and Baker V R (1976) Morphometry and floods in small drainage basins subject to diverse hydrogeomorphic controls, Water Resources Research, 12 (5), 941-952.

[22] Wentworth C K (1930) A Simplified Method of Determining the Average Slope of Land Surfaces, American Journal of Science 21, pp 184-194.

[23] Melton M A (1965) The geomorphic and paleoclimatic significance of alluvial deposits in southern Arizona. The Journal of Geology, 1-38. 